\title{
ANALISIS KANDUNGAN LOGAM BERAT As, Cd DAN Pb PADA Eucheuma cottonii DARI PERAIRAN TAKALAR SERTA ANALISIS MAXIMUM TOLERABLE INTAKE PADA MANUSIA
}

\author{
Sumarheni Sudir, Yulica Tumaruk, Burhanuddin Taebe, Tadjuddin Naid \\ Fakultas Farmasi, Universitas Hasanuddin, Makassar
}

Kata Kunci :

Asupan maksimal mingguan, Euchema cottonii, logam berat, Takalar

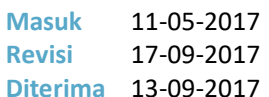

DOI

http://dx.doi.org/10.20956/mff.v $21 \mathrm{i} 3.6856$

Korespondensi

Sumarheni Sudir

sumarheni@unhas.ac.id

Fakultas Farmasi,

Universitas Hasanuddin

Jalan Perintis

Kemerdekaan Km.10,

Makassar 90245

Indonesia

Telp. +62-411-588-556

Fax. +62-411-585-188

Copyright

(C) 2017 Majalah Farmasi

Farmakologi Fakultas

Farmasi · Makassar

Diterbitkan tanggal

29-12-2017

Dapat Diakses Daring

Pada:

http://journal.unhas.ac.id

/index.php/mff

\begin{abstract}
ABSTRAK
Perairan Takalar Sulawesi Selatan telah dikenal sebagai lokasi budidaya alga terutama Eucheuma cottonii yang banyak dimanfaatkan sebagai bahan baku atau bahan tambahan pangan. Akan tetapi risiko terdapatnya cemaran logam berat yang berpotensi mengakibatkan gangguan kesehatan telah menjadi perhatian utama khususnya karena sifat dari tumbuhan air yang mampu menyerap logam berat sehingga terjadi akumulasi yang mengakibatkan kadar logam-logam tersebut lebih tinggi dibandingkan lingkungannya. Logam berat seperti timbal, kadmium dan arsen anorganik biasanya ditemukan dalam rumput laut dan pangan lain yang berasal dari laut. Penelitian ini bertujuan untuk mengetahui kandungan logam berat $\mathrm{Pb}, \mathrm{Cd}$, dan As pada E. cottonii dan mengetahui batas maksimum konsumsi mingguannya. Metode penelitian adalah metode studi lapangan dengan pengambilan sampel sebanyak 3 kali pengulangan. Analisis kadar logam berat menggunakan metode spektrometri serapan atom (SSA) sedangkan analisis keamanan konsumsi berdasarkan MTI (Maximum Tolerable Intake). Hasil penelitian menunjukkan bahwa kadar Pb pada sampel adalah 1,2215 $\pm 0,200 \mathrm{ppm}$, analisis kadar Cd di bawah batas deteksi, dan kadar As adalah 0,3939 $\pm 0,035 \mathrm{ppm}$. Berdasarkan kandungan logam berat $\mathrm{Pb}, \mathrm{Cd}$ dan $\mathrm{As}$, jumlah maksimum Eucheuma cottonii yang masih aman dikonsumsi per minggu oleh manusia dengan BB $60 \mathrm{~kg}$ adalah 122,8 g atau 0,1228 kg. Hasil penelitian ini menunjukkan bahwa kadar semua logam yang telah diteliti pada rumput laut Eucheuma cottonii warna hijau asal Kabupaten Takalar, Sulawesi Selatan masih memenuhi standar yang ditetapkan SNI dan BPOM, kecuali logam Pb karena hasilnya melebihi kadar yang seharusnya yaitu 1,0 mg/kg.
\end{abstract}

\section{PENDAHULUAN}

Alga hijau E.cottonii merupakan salah satu jenis rumput laut yang telah menjadi sumber daya alam laut Indonesia yang banyak dibudidayakan dan menjadi sumber pendapatan bagi masyarakat pesisir (1). Menurut Kementrian Kelautan dan Perikanan, nilai ekspor rumput laut pada tahun 2012 sebesar US\$ 178 juta, dengan volume mencapai 174.000 ton. Selain dapat digunakan langsung, beberapa hasil olahan rumput laut seperti agar-agar, alginat dan karaginan merupakan senyawa yang penting dalam industri pangan dan non pangan termasuk industri farmasi untuk bahan baku obat dan kosmetik. Selain itu rumput laut juga merupakan sumber kandungan bioaktif karena metabolit sekundernya telah terbukti dapat berfungsi sebagai antibakteri, antioksidan, antikanker, antikoagulan, dan antiviral $(2,3)$.

Saat ini perkembangan ilmu pengetahuan yang begitu pesat ikut mendukung berkembangnya kegiatan pembangunan sektor-sektor lainnya termasuk di bidang ekonomi. Perkembangan industri sebagai salah satu kegiatan pembangunan ekonomi secara tidak langsung menyebabkan menurunnya kualitas air pada lingkungan perairan, termasuk perairan yang digunakan untuk budidaya $(4,5)$. Penelitian yang dilakukan di beberapa wilayah perairan di Indonesia menunjukkan adanya cemaran logam berat tidak hanya pada air dan sedimen tetapi juga pada biota laut (6). Salah satu wilayah dengan tingkat produktivitas budidaya rumput laut yang tergolong tinggi di Sulawesi Selatan adalah
Perairan Takalar. Studi yang dilakukan oleh Teheni, M.T. and Syamsidar, H.S. pada tahun 2013 terhadap kadar logam Cd pada air laut beberapa lokasi di perairan Takalar menunjukkan kadar 0,3910-0,4725 ppm (7). Kadar logam yang jauh melebihi ambang batas sesuai PP RI No. 20/1990 yaitu $0,01 \mathrm{ppm}$, diperkirakan berasal dari cemaran bahan bakar kapal penangkap ikan dan mulai padatnya pemukiman di area pesisir. Meskipun hasil olahan rumput laut dari perairan Takalar berupa karaginan dan alginat tidak ditemukan mengandung logam berat $(8,9)$, akan tetapi penelitian terhadap logam berat $\mathrm{Pb}$, dan $\mathrm{Hg}$ yang terkandung dalam rumput laut Euchema cottonii dari daerah Takalar menyatakan bahwa kadar kedua logam ini melampaui batas aman yang ditetapkan oleh BPOM (10).

Logam berat seperti timbal, kadmium dan arsen anorganik biasanya ditemukan dalam rumput laut dan pangan lain yang berasal dari laut. Tumbuhan air seperti alga ataupun Bryophyta memiliki kemampuan untuk menyerap logam berat dari air sehingga membuat kadarnya di dalam tumbuhan menjadi lebih tinggi daripada yang ada di lingkungannya (11). Hal ini cukup mengkhawatirkan mengingat logam berat memiliki toksisitas yang tinggi $(12,13)$. Timbal terdapat dimana-mana dalam lingkungan, karena terdapat di alam dan digunakan dalam industri. Absorpsi timbal terutama melalui saluran cerna dan saluran nafas. Konsumsi timbal secara langsung dalam jumlah banyak dapat menyebabkan kerusakan jaringan terutama jaringan hati dan ginjal (14). 
Beberapa kerusakan yang disebabkan oleh toksisitas $\mathrm{Pb}$ terhadap kesehatan telah diidentifikasi termasuk gangguan pada sistem sintesis sel darah (hematopoetik) sehingga biosintesis hema terganggu, gangguan pada sistem saraf, gangguan reproduksi dan bahkan penghambatan pertumbuhan $(13,15)$. Toksisitas Kadmium (Cd) diantaranya disebabkan oleh sifatnya yang mampu berikatan dengan gugus $\mathrm{S}$ (sulfur) dan $\mathrm{COOH}$ dari molekul protein (asam amino dan amida). Logam berat ini juga memiliki kemampuan untuk menggantikan keberadaan logam-logam lain yang terdapat dalam metalloprotein seperti Cu dan Zn (16). Dalam kondisi asam lemah, kadmium akan mudah terabsorpsi ke dalam tubuh dan bersifat karsinogen juga racun kumulatif yang dapat merusak organ seperti ginjal, hati, paru-paru, system kardiovaskular, system immune dan sistem reproduksi $(17,18)$. Keracunan arsen (As) dapat terjadi melalui inhalasi maupun melalui digesti makanan dan minuman yang mengandung As. Paparan As baik akut maupun kronis dapat menyebabkan kerusakan pada system kardiovaskular, kecacatan dan gangguan pertumbuhan, kerusakan saraf, memicu terjadinya diabetes, gangguan pendengaran, kerusakan hematologi dan bahkan memicu timbulnya berbagai jenis kanker $(19,20,21)$.

Berdasarkan uraian di atas, maka pada penelitian ini akan dilakukan analisis kandungan logam yang terdapat pada rumput laut Eucheuma cottonii warna hijau yang diperoleh dari hasil budidaya di perairan Takalar. Maksud dilakukannya penelitian ini adalah memperoleh pengetahuan lebih lanjut mengenai kandungan logam pada rumput laut Eucheuma cottonii warna hijau dari Kabupaten Takalar, Sulawesi Selatan agar dapat menjadi bahan pertimbangan pihak konsumen maupun pemerintah dalam aspek keamanan jenis rumput laut ini terhadap cemaran. Tujuan penelitian ini adalah untuk mengetahui kadar logam $\mathrm{Pb}, \mathrm{Cd}$, dan As yang terkandung pada rumput laut Eucheuma cottonii warna hijau asal Kabupaten Takalar, Sulawesi Selatan dengan menggunakan metode spektrometri serapan atom (SSA).

\section{METODE PENELITIAN}

\section{Tempat Penelitian}

Penelitian dilaksanakan di Laboratorium Kimia Farmasi dan Laboratorium Biofarmaka Fakultas Farmasi Universitas Hasanuddin, Makassar. Determinasi sampel dilakukan di Bagian Laboratorium Biologi Laut, Fakultas Kelautan dan Ilmu Perikanan (FKIP), Universitas Hasanuddin.

\section{Penyiapan Sampel}

Sampel berupa alga hijau Eucheuma cottonii diperoleh dari hasil budidaya beberapa petani yang dipilih secara acak di Desa Punaga, Kecamatan Mangarabombang, Kabupaten Takalar. Sampel segar kemudian dibersihkan dari kotoran dengan menggunakan air mengalir dan pada pembilasan akhir digunakan air demineralisata. Pengeringan dilakukan pada oven simplisia bersuhu 50oC hingga diperoleh bobot tetap. Sampel kering diserbukkan menggunakan penghalus elektrik (Sico ®) hingga menjadi serbuk kasar (mesh 18).

\section{Pembuatan Kurva Kalibrasi Pb, Cd dan Zn}

Kurva kalibrasi logam $\mathrm{Pb}, \mathrm{Cd}$, dan As diperoleh dengan membuat larutan standar dengan beberapa variasi konsentrasi. Logam Pb dengan konsentrasi 1, 2, 4, 8, dan 10 ppb. Logam Cd pada konsentrasi 10, 15, 20, 25, dan 30 ppb. Serta logam As pada konsentrasi 10, 20, 30, 40, dan 50 ppb. Lalu diukur serapan larutan standar masing-masing logam pada kondisi optimumnya. Kemudian, dibuat kurva antara konsentrasi terhadap serapan masing-masing logam.

\section{Pengukuran Kadar Logam Pada Sampel}

Sampel berupa serbuk kering ditimbang sebanyak 0,5 gram lalu ditambahkan $10 \mathrm{ml}$ HNO3 p (Merck $\left.{ }^{\circledR}\right)$. Sampel dimasukkan ke dalam vessel pada microwave digester (MARS Chem ${ }^{\circledR}$ ) dan didestruksi pada suhu $150^{\circ} \mathrm{C}$ selama 45 menit. Selanjutnya sampel disaring dan dimasukkan ke labu tentukur $50 \mathrm{ml}$ lalu dicukupkan volumenya dengan air suling. Sampel kemudian diperiksa kandungan logam cadmium (Cd), timbal (Pb), dan arsen (As) menggunakan Spektrofotometer Serapan Atom (PinAAcle Perkin Elmer ${ }^{\circledR}$, GFA-7000 Shimadzu ${ }^{\circledR}$ pada masing-masing panjang gelombang maksimumnya.

Penentuan Batas Konsumsi Mingguan (Maximum Weekly Intake)

Sebagai dasar penentuan batas maksimum konsumsi per minggu untuk bahan pangan yang mengandung logam berat digunakan standar dari lembaga pangan internasional World Health Organization (WHO) dan Joint FAO/WHO Expert Committee on Food Additive (JEFCA). Perhitungan maksimum weekly intake menggunakan rumus:

$$
M W I(g)=\text { Berat Badan }^{a)} \times \text { PTWI }^{b)}
$$

\section{Keterangan:}

a): Untuk asumsi berat badan sebesar $60 \mathrm{~kg}$

b): PTWI atau Provisional Tolerable Weekly Intake (angka toleransi batas maksimum per minggu) yang dikeluarkan lembaga pangan terkait dalam satuan $\mathrm{mg} / \mathrm{kg}$ BB yang ditampilkan pada Tabel 1.

\begin{tabular}{|c|c|c|}
\hline No. & Jenis Logam & $\begin{array}{c}\text { PTWI } \\
(\mu \mathrm{g} / \mathrm{kgBB} / \text { minggu })\end{array}$ \\
\hline 1 & $\mathrm{~Pb}$ & 25 \\
\hline 2 & $\mathrm{Cd}$ & 7 \\
\hline 3 & As & 15 \\
\hline
\end{tabular}

Untuk mengetahui batasan jumlah konsumsi E. cottonii per minggu, maka nilai maksimum tolerable intake (MTI) dihitung dengan perumusan (Turkemen et al., 2008 dalam Mrajita, 2010):

$$
M T I=M W I / C t
$$

Keterangan:

MWI: Maksimum Weekly Intake ( $\mu$ g untuk orang dengan BB $60 \mathrm{~kg}$ per minggu)

Ct: Konsentrasi logam berat yang ditemukan di dalam sampel $(\mu \mathrm{g} / \mathrm{g})$

\section{HASIL DAN PEMBAHASAN}

Pada penelitian ini dilakukan pengukuran kandungan logam dari rumput laut Eucheuma cottonii yang diperoleh dari hasil budidaya petani rumput laut di desa Punaga, kabupaten Takalar. Sebelum analisis, dilakukan proses determinasi yang menunjukkan bahwa sampel dalam penelitian ini adalah Kappaphycus alvarezii Doty, yang lebih dikenal dengan nama Eucheuma cottonii. Pada tahap preparasi sampel, proses destruksi dilaksanakan menggunakan alat microwave digester. Metode ini dipilih karena lebih sederhana, lebih cepat, dan mengurangi kemungkinan hilangnya sejumlah analit, yang biasanya terjadi jika sampel diabukan dengan cara manual (22). Kandungan logam dalam sampel yang telah didestruksi kemudian diukur menggunakan metode Spektrofotometri Serapan Atom sehingga mampu mendeteksi elemen dengan jumlah yang sangat kecil (ppm) 
secara spesifik (23).Hasil pengukuran kadar logam berat $\mathrm{Pb}$, Cd, dan As pada sampel E. cottonii disajikan pada Tabel 2.

Tabel 2. Hasil pengukuran kadar Timbal ( $\mathrm{Pb}$ ), Kadmium (Cd) dan Arsen (As) Sampel Eucheuma cottonii dengan spektrofotometer Serapan Atom

\begin{tabular}{|c|c|c|}
\hline Logam & Replikasi & Konsentrasi (ppm) \\
\hline & 1 & 1,2059 \\
\hline \multirow[t]{4}{*}{$\mathrm{Pb}$} & 2 & 1,2441 \\
\hline & 3 & 1,2145 \\
\hline & & Rata-rata $\pm S D \quad 1,2215 \pm 0,200$ \\
\hline & 1 & 0,0000 \\
\hline \multirow[t]{4}{*}{$\mathrm{Cd}$} & 2 & 0,0000 \\
\hline & 3 & 0,0000 \\
\hline & & $0,0000 \pm 0,000$ \\
\hline & 1 & 0,4207 \\
\hline \multirow[t]{3}{*}{ As } & 2 & 0,4070 \\
\hline & 3 & 0,3542 \\
\hline & & $0,3939 \pm 0,035$ \\
\hline
\end{tabular}

Timbal $(\mathrm{Pb})$ merupakan salah satu logam berat yang paling banyak mencemari perairan, hal ini disebabkan karena timbal merupakan salah satu limbah hasil penguraian bahan bakar yang digunakan oleh kapal. Saat tubuh manusia terpapar oleh timbal, maka timbal akan dibawa oleh sel darah merah dan didistribusikan ke jaringan lunak (ginjal dan hati); didistribusikan kembali ke tulang, gigi, dan rambut biasanya dalam bentuk garam fosfat. Mekanisme toksisitasnya sendiri dikarenakan timbal dapat menghambat biosintesis heme, dan juga dapat berikatan dengan gugus sulfidril pada protein. Hasil pengukuran logam $\mathrm{Pb}$ menggunakan teknik Graphyte Furnace Atomic Absorption (GFAA) terhadap 3 replikasi sampel menunjukkan bahwa kandungan logam berat $\mathrm{Pb}$ pada rumput laut melebihi ambang batas yang ditetapkan oleh Badan Standarisasi Nasional dan BPOM untuk sampel bahan pangan rumput laut yaitu $1,0 \mathrm{mg} / \mathrm{kg}$ (24). Hasil ini tidak jauh berbeda dibandingkan kadar $\mathrm{Pb}$ sampel E.cottonii pada penelitian Hanafi, H. tahun 2009 (10) dan sampel E.spinosum dari perairan Takalar yakni berkisar antara 0,99 $1,7024 \mathrm{mg} / \mathrm{kg}(25)$.

Kadmium merupakan jenis logam berat yang bila terpapar pada tubuh manusia maka akan berikatan dengan albumin dan juga sel darah serta metallothionin pada jaringan hati dan ginjal. Jika terpapar oral, maka bisa menyebabkan luka pada tubulus proksimal ginjal. Gejala keracunan akut kadmium berupa muntah, dan diare. Sedangkan gejala keracunan kronis yaitu terjadinya nefrotoksisitas. Hasil pengukuran kadmium terhadap 3 replikasi dengan menggunakan teknik Flame AA menunjukkan bahwa ketiga replikasi memiliki nilai serapan yang sangat kecil sehingga menunjukkan bahwa kandungan logam $\mathrm{Cd}$ pada sampel tidak terdeteksi atau di bawah limit pengukuran alat. Hasil penelitian ini sangat berbeda dibandingkan penelitian Teheni, MT., et al., 2016 (7) yang menunjukkan tingginya kadar Cd hingga mencapai 0,2920 ppm pada sampel E. cottonii yang berasal dari perairan Bantaeng yang terletak di perbatasan Kabupaten Takalar.

Logam arsen merupakan salah satu jenis logam yang cukup berbahaya. Saat terpapar pada tubuh manusia, maka akan terakumulasi pada paru-paru, jantung, ginjal, hati, otot, dan jaringan saraf. Mekanisme toksisitasnya: pada membran akan merusak protein karena meningkatnya kapilaritas endotelium, dapat menghambat enzim yang mengandung gugus sulfidril, dan juga menghambat fosforilasi anaerob dan oksidatif. Pada pengukuran arsen yang dilakukan terhadap replikasi 1, 2, dan 3 dengan teknik Graphyte Furnace Atomic Absorption (GFAA) diperoleh hasil masing-masing 0,4207 ppm, 0,4070 ppm, dan 0,3542 ppm dengan rata-rata 0,3939 ppm. Hasil ini menunjukkan bahwa kandungan logam As pada sampel masih sesuai dengan yang ditetapkan oleh
Badan Standarisasi Nasional dan BPOM yaitu tidak lebih dari $1,0 \mathrm{mg} / \mathrm{kg}(24)$.

Jumlah maksimum sampel E.cottonii yang masih aman dikonsumsi per minggu menurut rumus Turkemen et al. (2008) dalam Mrajita tahun 2010 (26) ditampilkan di dalam Tabel 3. Nilai MWI logam $\mathrm{Pb}$ yang dapat dikonsumsi manusia berbobot badan $60 \mathrm{~kg}$ adalah sebesar $1500 \mu \mathrm{g}$ atau 0,0015 gram per minggu. Apabila terdapat intake logam berat $\mathrm{Pb}$ melebihi nilai MWI tersebut, maka akan terjadi reaksi toksik berupa keracunan akut $\mathrm{Pb}$ dapat menyebabkan gangguan fungsi otak, pertumbuhan (27), disfungsi hati maupun ginjal (28) dan gangguan reproduksi (29). Ditambahkan lagi bahwa dosis yang menyebabkan lethal (kematian) manusia diperkirakan terjadi jika $500 \mathrm{mg}$ atau 0,5 gram $\mathrm{Pb}$ terserap ke dalam tubuh (30). Sampel E. cottonii dari perairan Takalar mengandung kadar $\mathrm{Pb}$ sebanyak 1,2215 $\pm 0,200 \mathrm{ppm}$. Oleh karena itu, nilai Maximum Tolerable Intake sampel yakni 122,80 g per minggu.

Tabel 3. Hasil pengukuran kadar Timbal (Pb), Kadmium (Cd) dan Arsen (As) Sampel Eucheuma cottonii dengan spektrofotometer Serapan Atom

\begin{tabular}{cccc}
\hline No Jenis Logam & $\begin{array}{c}\text { PTWI } \\
(\mu \mathrm{g} / \mathbf{k g} \text { BB /minggu }\end{array}$ & $\begin{array}{l}\text { MTI } \\
(\mathbf{k g})\end{array}$ \\
\hline 1. & $\mathrm{~Pb}$ & 25 & 0,1228 \\
\hline 2. & $\mathrm{Cd}$ & 7 & $\begin{array}{c}\text { Tidak dapat } \\
\text { ditentukan }\end{array}$ \\
\hline 3. & As & 15 & 2,2848 \\
\hline
\end{tabular}

Nilai MWI logam Cd untuk manusia berbobot badan $60 \mathrm{~kg}$ adalah sebesar $420 \mu \mathrm{g}$ atau 0,00042 gram per minggu. Logam Cd akan bersifat toksik pada tubuh manusia jika terdapat asupan melebihi jumlah tersebut yakni dapat berupa disfungsi ginjal, gangguan sistem syaraf maupun reproduksi, resiko karsinogenik dan kanker prostat (31). Kadar Cd pada Sampel E. cottonii dari perairan Takalar tidak terdeteksi atau di bawah batas deteksi alat. Oleh karena itu, nilai MTI sampel tidak dapat diketahui atau dengan kata lain, sampel aman dikonsumsi tanpa perlu mengkhawatirkan risiko keracunan Cd.

Selanjutnya, nilai MWI As untuk manusia dengan bobot badan $60 \mathrm{~kg}$ yaitu sebesar $900 \mu \mathrm{g}$ per minggu. Asupan pangan yang mengandung As melebihi kadar tersebut berisiko timbulnya kerusakan terhadap organ respirasi, dan dapat juga menyebabkan timbulnya kanker. Nilai MTI untuk logam berat As menunjukkan bahwa manusia dengan BB $60 \mathrm{~kg}$ dapat mengkonsumsi sampel E.cottonii asal perairan Takalar sebanyak 2,2848 $\mathrm{kg}$ per minggu.

Dengan demikian, berdasarkan kandungan logam berat $\mathrm{Pb}$, Cd dan As pada sampel yang dibudidayakan di Desa Punaga, Kecamatan Mangarabombang, Kabupaten Takalar, jumlah maksimum Eucheuma cottonii yang masih aman dikonsumsi per minggu oleh manusia dengan BB $60 \mathrm{~kg}$ adalah 122,8 g atau $0,1228 \mathrm{~kg}$

\section{KESIMPULAN}

Berdasarkan hasil penelitian yang telah dilakukan maka dapat disimpulkan bahwa: (1) Analisis kadar logam berat pada sampel rumput laut Euchema cottonii asal perairan Takalar menunjukkan bahwa kadar $\mathrm{Pb}$ pada sampel adalah $1,2215 \pm 0,200$ ppm, analisis kadar Cd di bawah batas deteksi, dan kadar As adalah 0,3939 $\pm 0,035 \mathrm{ppm}$. Kandungan logam berat $\mathrm{Pb}$ pada sampel Euchema cottonii lebih tinggi dari ambang batas yang ditetapkan oleh SNI dan BPOM sedangkan kadar As dan Cd memenuhi persyaratan. (2) Analisis 
keamanan konsumsi berdasarkan MTI (Maximum Tolerable Intake) kandungan logam berat $\mathrm{Pb}, \mathrm{Cd}$ dan As pada sampel rumput laut Euchema cottonii asal perairan Takalar, jumlah maksimum Eucheuma cottonii yang masih aman dikonsumsi per minggu oleh manusia dengan BB $60 \mathrm{~kg}$ adalah 122,8 g atau $0,1228 \mathrm{~kg}$.

\section{DAFTAR PUSTAKA}

1. Bawa P, Laila I. Penentuan pH optimum isolasi karaginan dari rumput laut jenis Kappaphycus alvarezii. JK1 [Internet]. 1(1). Tersedia pada: http://ejournal.unud.ac.id/abstrak/j-kim-vol1-no1-bawa.pdf

2. Rajauria G, Jaiswal AK, Abu-ghanam N, Gupta S. Antimicrobial Antioxidant, and Free Radical Scavening Capacity of Brown Seaweed Himanthalia Elongata from Western Coast of Ireland. Irlandia: Dublin Institute of Technology; 2012.

3. Naid T, Kasim SM, Sumarheni. Produksi Antibiotika Secara Fermetas dari Biakan Mikroorganisme Simbion Rumput Laut Euchema contonii. Maj Farm dan Farmakol. 2013;17:61-9.

4. Yulianto B, Ario R, Triono A. Daya Serap Rumput Laut (Gracilaria sp) Terhadap Logam Berat Tembaga (Cu) Sebagai Biofilter. Semarang: FPIK Universitas Diponegoro; 2006.

5. Qari R, Siddiqui SA. A Comparative Study of Heavy Metal Concentration in Red Seaweeds from Different Coastal Areas Of Karachi, Arabian Sea. University of Karachi. Pakistan; 2010.

6. Susiati. Kandungan logam berat $(\mathrm{Cu}, \mathrm{Cr}, \mathrm{Zn}, \mathrm{dan} \mathrm{Fe})$ pada terumbu karang di perairan pulau panjang. Jepara; 2008.

7. Teheni MT, Syamsidar HS. Penentuan Kadar dan Distribusi Spasial Logam Berat Kadmium (Cd) pada Rumput Laut Euchema cottonii Asal Perairan Kab. Takalar dengan Metode Spektrofotometer Serapan Atom (SSA). Al-Kimia. 2013;1(1):30-41.

8. Diharmi A. Karakteristik Fisiko-Kimia Karagenan Rumput Laut Merah Eucheuma Spinosum dari Perairan Nusa Penida, Sumenep, dan Takalar. Doctoral dissertation, IPB (Bogor Agricultural University).

9. Kasim S, Marzuki A, Sudir S. Effects Of Sodium Carbonate Concentration And Temperature On The Yield And Quality Characteristics Of Alginate Extracted From Sargassum sp. Res J Pharm Biol Chem Sci (RJPBCS)s. 2017;8(1):660-8

10. Hanafi H. Analisis Kadar Logam Timbal, Merkuri, Kalsium, dan Besi pada Rumput Laut Merah (Euchema cottonii) Asal Kabupaten Takalar. 2009.

11. Whitton BA, Say PJ, Wehr JD. Use of plants to monitor heavy metals in rivers. In: Metals in Northern England: Environmental and Biological aspects. Universitas Durham, Departemen Botani; 1981. 135-45.

12. Whitton B. Zinc and plants in rivers and stream. In: Zinc in environment New York: John Wiley \& Sons Inc; 1980. 364-400.
13. Tchounwou PB, Yedjou CG, Patlolla AK, Sutton DJ. Heavy metal toxicity and the environment. In: Molecular, clinical and environmental toxicology. Springer, Basel; 2012. 133-64.

14. Mudipalli A. Lead hepatotoxicity \& potential health effects. Indian J Med Res. 2007;126(6):518.

15. Mahaffey KR. Nutritional factors and susceptibility to lead toxicity. Environ Health Perspect. 1974;7:107.

16. Nath R, Prasad R, Palinal VK, Chopra RK. Basis of cadmium toxicity. Prog Food Nutr Sci. 1984;8(1-2):109-63.

17. Fowler BA. Monitoring of human populations for early markers of cadmium toxicity: a review. Toxicol Appl Pharmacol. 2009;238(3):294300.

18. Godt J, Scheidig F, Grosse-Siestrup C, Esche V, Brandenburg P, Reich A The toxicity of cadmium and resulting hazards for human health. J Occup Med Toxicol. 2006;1(1):22.

19. Sjamsudin U. Logam Berat dan Antagonis. Gan S, editor. In: Farmakologi dan Terapi Edisi IV. Jakarta: Bagian Farmakologi FK UI; 1995. 790-3.

20. Tchounwou PB, Centeno JA, Patlolla AK. Arsenic toxicity, mutagenesis, and carcinogenesis-a health risk assessment and management approach. Mol Cell Biochem. 2004;255(1-2):47-55.

21. Choong TS, Chuah TG, Robiah Y, Koay FG, Azni I. Arsenic toxicity, health hazards and removal techniques from water: an overview. Desalination. 2007;217(1-3):139-66.

22. El-Naggar MEE, Al-Amoudi OA. Heavy Metal Level in Several Species of Marine Algae from the Red Sea of Saudi Arabia. Saudi Arabia: Department of Biology, Faculty of Applied Science, Umm Al-Qura University; 1989.

23. Vogel, Israel A. Vogel's: Textbook of Quantitative Chemical Analysis. 5 ed. New York: John Wiley \& Sons Inc; 1989. 785-794.

24. Badan Standarisasi Nasional. Batas Cemaran Logam Berat dalam Pangan.pdf. 2009.

25. Rahmawati R, Basarang M. Determination Of Plumbum (Pb) Seaweed Sargassum sp. and Eucheuma spinosum in Water Puntondo Regency of Takalar South Sulawesi. Mar Chim Acta. 2017;18(2).

26. Mrajita CVP. Kandungan Logam Berat pada Beberapa Biota Kekerangan di Kawasan Littoral Pulau Adonara (Kabupaten Flores Timur, Nusa Tenggara Timur) dan Aplikasinya dalam Analisis Keamanan Konsumsi Publik. Program Magister Manajemen Sumberdaya Pantai Universitas Diponegoro Semarang; 2010.

27. Mukarami K, Feng G, Chen SG. Inhibition of Brain Kinase Subtypes by Lead. J Pharmacol Exp Ther. 1993;264(2):757-61.

28. Cullen G, Dines A, Kolev S. Lead IPCS INTOX-Data Bank. London: National Poison Information Service; 2005

29. Juberg DR, Kleiman CF, Kwan SC. Lead and Human Health. American Council on Science and Health. New York; 1977. 1-42.

30. Rahde AF. Lead Inorganic. IPCS INCHEM; 1991. 1-24.

31. APHA. Standart Method for The Examination of Water and Wastewater. 18 ed. Washington; 1992. 2552 